\title{
FACTORS AFFECTING THE PERFORMANCE OF HEALTH WORKERS AT THE COMMUNITY HEALTH CENTERS IN KLATEN, CENTRAL JAVA
}

\author{
Nia Handayani ${ }^{1)}$, Didik Gunawan Tamtomo'), Bhisma Murti ${ }^{1)}$ \\ ${ }^{1)}$ Masters Program in Public Health, Universitas Sebelas Maret \\ 2)Faculty of Medicine, Universitas Sebelas Maret
}

\begin{abstract}
Background: Stress is unavoidable on workplaces, employees who feel stress are more likely to be less motivated, less satisfied, show poor performance, and less productivity. The purpose of this study was to examine factors affecting the performance of health workers at the community health centers in Klaten, Central Java.

Subjects and Method: A cross sectional study was conducted at community health centers in Klaten, Central Java, from November to December 2019. A sample of 200 health workers was selected by stratified random sampling. The dependent variable was work performance. The independent variables were work stress, education, tenure, leadership style, and type of work. The data were collected by questionnaire and analyzed by a multiple logistic regression run on Stata 13.

Results: Health workers performance increased with democratic leadership style $(b=1.40$; $95 \% \mathrm{CI}=0.44$ to $2.36 ; \mathrm{p}=0.004$ ), education (undergraduate and magister) $(\mathrm{b}=1.58 ; 95 \% \mathrm{CI}=$ 0.65 to $2.52 ; \mathrm{p}=0.001)$, tenure $\geq 6$ years $(\mathrm{b}=1.72 ; 95 \% \mathrm{CI}=0.73$ to $2.70 ; \mathrm{p}=0.001)$, single job $(\mathrm{b}=2.05 ; 95 \% \mathrm{CI}=1.07$ to $3.03 ; \mathrm{p}<0.001)$. Health workers performance decreased with high work stress $(b=-1.65 ; 95 \% \mathrm{CI}=-2.58$ to $-0.72 ; \mathrm{p}=0.001)$.

Conclusion: Health workers performance increases with democratic leadership style, education, tenure $\geq 6$ years, and single job. Health workers performance decreases with high work stress.
\end{abstract}

Keywords: work performance, heath workers, stress, leadership style

\section{Correspondence:}

Nia Handayani. Masters Program in Public Health, Universitas Sebelas Maret. Jl. Ir. Sutami 36A, Surakarta 57126, Central Java, Indonesia. Email: niahandayani19@gmail.com. Mobile: +6282133055176 .

The $7^{\text {th }}$ International Conference on Public Health Solo, Indonesia, November 18-19, 2020 | 355 https://doi.org/10.26911/the7thicph.04.40 